\title{
Assessment Of Critical Business Skill Development By MBA Alumni
}

Joseph G. Glynn, Canisius College

Gregory R. Wood, Canisius College

\begin{abstract}
Six years of survey data were analyzed to assess, among other things, the degree to which an AACSB accredited graduate business program successfully developed student skills in a variety of areas deemed important for career success. The study illustrates a methodology institutions can use to respond to increasing demands for program evaluation and assessment of learning goals. As well, data on program efficacy can impact a program's marketing efforts in attracting students in an increasingly competitive marketplace.
\end{abstract}

Keywords: MBA Alumni, Surveys, Critical Skills, Assessment of Learning

\section{INTRODUCTION}

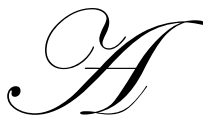

number of "consumer" oriented studies have been conducted over the past decade by researchers in higher education. This body of research has yielded insights on factors affecting student assessment of institutional quality (Browne, et al. 1998), factors affecting college choice (Ashar \& Lane, 1996), curriculum design (Franzak \& Cowles, 1993), employer perceptions of service quality (Joseph \& Joseph, 1997), and student expectations (Panitz, 1995). The current study extends this work by identifying how graduates of an MBA program perceive the relative importance of various skills and the degree to which their graduate program curriculum developed those skills.

The study reported herein was conducted at a comprehensive mid-size private college in an urban area of the northeastern United States. This work reports on results of MBA alumni surveys for classes graduating between 1995 - 2000. The MBA alumni surveys are a part of a larger project that entails the administration of seven surveys annually. We conduct biannual surveys of our (a) new MBA matriculates, (b) graduating MBAs, and (c) graduating undergraduates. An MBA alumni class is selected and surveyed once each year. The terms "MBA" and "graduate business program" will be used interchangeably in this work.

By design, there are many similarities among the three surveys administered to MBAs (new matriculates, graduating MBAs, and alumni). Each respondent group has distinct characteristics and perspectives, but members of each group clearly share more common characteristics than uniquenesses. After all, they are the same people at different points in time and in their careers. For example, a student may have been surveyed as a new matriculate in 1996, surveyed again as a graduating MBA in 1999, and surveyed yet again as an MBA alumnus in 2003. The surveys have several items in common to accommodate comparisons across the three important client groups. Previous studies (Glynn 2004 and Glynn 2005) have reported on the surveys administered to the new MBA matriculates and the graduating MBAs. Portions of those works will be replicated in the Background section below.

\section{BACKGROUND}

The host institution has had a part-time evening MBA program since about 1970, and it has been accredited by the AACSB since 1982. In 2000, a full-time one-year MBA program was successfully launched. This work focuses solely upon the part-time evening MBA program, which is by far the larger program. The primary motivations for the survey research include: (a) a commitment to providing a quality graduate business education 
that delivers current material over appropriate topics, (b) the institution operates in a highly competitive environment for attracting MBA students, and (c) maintenance of AACSB accreditation.

Our average graduate business program enrollment has been about 350 over the last ten years. Most of the students are local, full-time professionally employed people. Competition for MBA students has become intense. The local metropolitan area supports several other MBA programs, two of which are AACSB accredited. Our main competition appears to come from two sources. The first is a large public university with both AACSB accredited full-time day and part-time evening MBA programs and a deserved national reputation. The second is a recent upstart program with an enviable advertising budget promoting a shorter (fewer credit hours) and highly flexible program that is not AACSB accredited. Since we are a private institution with, except for a few adjunct faculty, 100 percent terminally qualified faculty, our program is more costly to students than either of these programs, or any of the several other MBA programs in the area. Company-sponsored tuition reimbursement programs are important to our students. Since the local economy has not fared as well as the national economy, many tuition reimbursement programs have been scaled back.

\section{SURVEY CONTENT AND GOALS}

We have been surveying our graduate business programs alumni since 1990. We learned much about our students and their opinions about our programs. We used their inputs and responses to open-end questions, as well as small group interviews, to improve the survey instrument. The survey instrument has, with few exceptions, remained fixed since the summer of 1997 . We administer the surveys during the early summer. We surveyed three different classes in each summer over the years 1997 - 2000. For example, in 1997 we surveyed classes that graduated in 1982, 1987, and 1992. Beginning in the summer of 2001 we decided to scale back the number of classes surveyed annually. We initiated a plan to survey only one class per year - the class that graduated four years earlier. So, in the summer of 2001, the MBA class of 1997 was surveyed, in the summer of 2002, the class of 1998 was surveyed, and so on.

The survey was intentionally designed to be brief, and can easily be completed in five minutes. We wanted to find out how satisfied alumni were with their MBA Program and experiences, and we sought to collect data on their employment activities. Demographic and descriptive background characteristics were of interest as well. As with all of the survey research we do at the host institution, we deemed it to be of paramount importance to track any changes or trends in these data over time.

Respondents were also asked a few evaluative open-end questions concerning:

- Reasons they would or would not recommend our MBA Program,

- Identification of the best features/attributes of our program, and

- $\quad$ Recommendations for improving our program.

The primary focus of this research is directed towards assessments of nine skills that have been determined to be critical to our Graduate Business Program curriculum. Identification of these skills was motivated in great part by language in the AACSB Standards for Business Accreditation. The skills are listed below in the order that they appear on the survey.

$\begin{array}{ll}\text { - } & \text { Ability to Work Independently } \\ \text { - } & \text { Quantitative Skills } \\ \text { - } & \text { Intesentation Skills } \\ \text { - } & \text { Problem-Solving Skills } \\ \text { - } & \text { Team Building Skills } \\ \text { - } & \text { Writing Skills } \\ \text { - } & \text { Computer Skills } \\ & \text { Critical Thinking Skills }\end{array}$


With respect to the above skills, MBA alumni were asked to give up to three responses to each of the following items.

- Which skills (if any) were MOST IMPROVED? (i.e., $1^{\text {st }}, 2^{\text {nd }}$, and $3^{\text {rd }}$ most improved)

- Which skills (if any) were LEAST SUCCESSFULLY DEVELOPED?

- Which skills do you feel are MOST IMPORTANT TO YOUR PROFESSIONAL GOALS AND DEVELOPMENT?

\section{RESULTS}

Table 1 summarizes the sample size and response rates for the alumni surveys from 1995 to 2000.

Table 1

Respondent Counts and Response Rates by Graduation Year

\begin{tabular}{|c|c|c|c|c|c|c|}
\hline & $\mathbf{1 9 9 5}$ & $\mathbf{1 9 9 6}$ & $\mathbf{1 9 9 7}$ & $\mathbf{1 9 9 8}$ & $\mathbf{1 9 9 9}$ & $\mathbf{2 0 0 0}$ \\
\hline Count & 23 & 32 & 27 & 35 & 31 & 19 \\
\hline Response Rate & $20 \%$ & $23 \%$ & $30 \%$ & $36 \%$ & $26 \%$ & $19 \%$ \\
\hline
\end{tabular}

\section{Descriptive Student Profiles}

Table 2 below summarizes some pertinent data with respect to demographic and professional profiles of our MBA alumni. Though there are some anomalies in the data (i.e., only 18.7 percent of respondents were women and 26.9 percent of respondents worked in the field of education for the class of 1996) there do not appear to be any notable trends.

Table 2

Descriptive Student Profiles - All Figures Are Percents

\begin{tabular}{|c|c|c|c|c|c|c|c|c|}
\hline & & 1995 & 1996 & 1997 & 1998 & 1999 & 2000 & Total \\
\hline \multirow[t]{2}{*}{ Gender } & Female & 50.0 & 18.7 & 38.5 & 51.5 & 40.0 & 36.8 & 38.9 \\
\hline & Male & 50.0 & 81.3 & 61.5 & 48.5 & 60.0 & 63.2 & 61.1 \\
\hline \multirow[t]{5}{*}{ Age } & $\leq 35$ & 40.9 & 65.6 & 61.5 & 51.5 & 53.3 & 42.1 & 53.7 \\
\hline & $36-40$ & 31.8 & 18.8 & 23.1 & 18.2 & 13.3 & 31.6 & 21.6 \\
\hline & $41-45$ & 22.7 & 3.1 & 11.5 & 24.2 & 23.3 & 15.8 & 16.7 \\
\hline & $46-50$ & 4.5 & 6.3 & 3.8 & 6.1 & 6.7 & 5.3 & 5.6 \\
\hline & $\geq 51$ & 0 & 6.3 & 0 & 0 & 3.3 & 5.3 & 2.5 \\
\hline \multirow{2}{*}{$\begin{array}{l}\text { Recommend } \\
\text { MBA Program? }\end{array}$} & Yes & 90.99. & 87.5 & 100 & 85.7 & 96.7 & 94.7 & 92.7 \\
\hline & No & 1 & 12.5 & 0 & 14.3 & 3.3 & 5.3 & 7.3 \\
\hline \multirow{4}{*}{$\begin{array}{l}\text { Employment } \\
\text { Status }\end{array}$} & Full-Time & 95.5 & 90.7 & 96.3 & 90.9 & 87.1 & 94.4 & 92.7 \\
\hline & Part-Time & 4.5 & 3.1 & 0 & 3.0 & 0 & 0 & 1.8 \\
\hline & Self-Employed & 0 & 3.1 & 3.7 & 3.0 & 3.2 & 0 & 1.8 \\
\hline & Unemployed & 0 & 3.1 & 0 & 3.0 & 9.7 & 5.6 & 3.6 \\
\hline \multicolumn{9}{|c|}{ Items below for full-time employed only } \\
\hline \multirow{9}{*}{$\begin{array}{l}\text { Industry } \\
\text { [for full-time } \\
\text { employed only] }\end{array}$} & Manufacturing & 14.3 & 23.1 & 16.7 & 17.2 & 32.1 & 23.5 & 21.4 \\
\hline & Banking/Financial & 19.0 & 23.1 & 29.2 & 17.2 & 7.1 & 17.6 & 18.6 \\
\hline & Health Care & 23.8 & 0 & 16.7 & 6.9 & 3.6 & 0 & 8.3 \\
\hline & Other Service & 0 & 19.2 & 8.3 & 17.2 & 3.6 & 0 & 9.0 \\
\hline & Education & 4.8 & 26.9 & 0 & 6.9 & 0 & 11.8 & 8.3 \\
\hline & Sales/Distribution & 9.5 & 0 & 0 & 6.9 & 3.6 & 17.6 & 5.5 \\
\hline & Computers/Telecom & 4.8 & 0 & 0 & 3.4 & 10.7 & 5.9 & 4.1 \\
\hline & Fed,State,Local Govt. & 19.1 & 7.6 & 8.3 & 10.3 & 0 & 0 & 7.7 \\
\hline & Other & 4.7 & 0 & 20.8 & 13.8 & 39.3 & 23.6 & 17.1 \\
\hline \multirow{4}{*}{$\begin{array}{l}\text { Respondent's } \\
\text { Level in } \\
\text { Organization }\end{array}$} & Upper Management & 19.0 & 15.4 & 26.1 & 26.7 & 28.6 & 17.6 & 22.8 \\
\hline & Middle Management & 42.9 & 42.3 & 30.4 & 33.3 & 25.0 & 35.3 & 34.5 \\
\hline & Supervisory & 19.0 & 15.4 & 13.0 & 10.0 & 14.3 & 5.9 & 13.1 \\
\hline & Non-Management & 19.0 & 26.9 & 30.4 & 30.0 & 32.1 & 41.2 & 29.7 \\
\hline
\end{tabular}


We are pleased with the generally high percents of alumni who would recommend our MBA Program, yet some attention should perhaps be directed towards the classes of 1995, 1996, and 1998 where 9.1 percent, 12.5 percent, and 14.3 percent respectively would not recommend our program. Fortunately, the survey provided a means of investigating potential sources of dissatisfaction. Respondents were asked to list up to three reasons they would not recommend our program. A summary of these reasons compiled over the classes of 1995, 1996, and 1998 appears below. There were only 11 total respondents ( 2 in 1995, 4 in 1996, and 5 in 1998) who did not recommend our program. So the $45.5 \%$ for High Tuition means that 5 of the 11 named High Tuition as one of up to three reasons they would not recommend our MBA Program.

Table 3

Summary Of Reasons For Not Recommending Program: Classes of 1995, 1996, and 1998

\begin{tabular}{|l|c|c|}
\hline \multicolumn{1}{|c|}{ Reason For Not Recommending Program } & Frequency & $\begin{array}{c}\text { Percent of Respondents Who } \\
\text { Would Not Recommend Program }\end{array}$ \\
\hline High Tuition & 5 & $45.5 \%$ \\
\hline Don't Like 1.5 Credit Module Classes & 2 & $18.2 \%$ \\
\hline Want More Real World Material, Experiences In Courses & 2 & $18.2 \%$ \\
\hline Provide better job search services & 2 & $18.2 \%$ \\
\hline
\end{tabular}

\section{Factors Motivating Students To Recommend MBA Program}

Shifting focus to more positive results, respondents who would recommend our program were asked to list up to three important factors, which motivated their response to recommend. Table 4 below summarizes these responses over the classes of $1995-2000$.

Recall that responses in Table 4 (and Table 3) were supplied to open-end questions on the survey. So of the MBA alumni who would recommend the program, 34.9 percent named Faculty Competence as one of up to three important factors that motivated them to recommend our MBA Program. The top four reasons in Table 4 form the most dominant grouping with response rates between 34.9 percent for Faculty Competence and 22.4 percent for Program Reputation. Three of these four - Faculty Competence, Quality of Program, and Program Reputation - all relate to perceived quality of our program. The fourth, Small Class Size, is a program attribute that we are certain would be greatly valued in any graduate (or for that matter, undergraduate) program. We are pleased that our alumni both recognize and assign high value to the quality dimensions of our Graduate Business Programs.

Table 4

Summary Of Reasons For Recommending Program: Classes Of 1995 - 2000

\begin{tabular}{|l|c|c|}
\hline \multicolumn{1}{|c|}{ Reason For Recommending Program } & Frequency & $\begin{array}{c}\text { Percent of Respondents Who } \\
\text { Would Recommend Program }\end{array}$ \\
\hline Faculty Competence & 53 & $34.9 \%$ \\
\hline Small Class Size & 43 & $28.3 \%$ \\
\hline Quality Of Program & 35 & $23.0 \%$ \\
\hline Program Reputation & 34 & $22.4 \%$ \\
\hline Flexibility In Scheduling & 26 & $17.1 \%$ \\
\hline Personal Attention & 25 & $16.4 \%$ \\
\hline Accommodate Working Student & 17 & $11.2 \%$ \\
\hline Faculty With Real World Experience & 12 & $7.9 \%$ \\
\hline General Location & 12 & $7.9 \%$ \\
\hline AACSB Accreditation & 9 & $5.9 \%$ \\
\hline Networking/Ties To Business Community & 9 & $5.9 \%$ \\
\hline Variety Of Courses/Electives & 9 & $5.9 \%$ \\
\hline
\end{tabular}


The next three reasons mentioned for recommending our program are Flexibility in Scheduling, Personal Attention, and Accommodate Working Student, with response rates ranging from 17.1 percent to 11.2 percent. This group of responses could be labeled "comfort attributes" of the program. All three are concerned with accommodations of needs of the full-time working students who were dominant among the respondents to the survey (see Table 2).

\section{Ratings Of Skills That Were Most Improved}

Recall that the main goal of this research was to evaluate respondent opinions with respect to nine skills that we have identified as being critical to graduate business education. Specifically, we were eager to learn which skills were most improved, least successfully developed, and most important in the opinions of our MBA alumni. The reader should note that $2^{\text {nd }}$ and $3^{\text {rd }}$ mentions are not included in Tables $5-11$. Thus, Table 5 depicts results for the most improved skill and Table 6 displays the rankings of the most improved skill.

Table 5

Most Improved Skill

\begin{tabular}{|c|c|c|c|c|c|c|c|c|}
\hline & & 1995 & 1996 & 1997 & 1998 & 1999 & 2000 & Totals \\
\hline Quantitative & $\begin{array}{l}\mathbf{n} \\
\%\end{array}$ & $\begin{array}{c}5 \\
21.7 \\
\end{array}$ & $\begin{array}{c}9 \\
29.0 \\
\end{array}$ & $\begin{array}{c}5 \\
18.5 \\
\end{array}$ & $\begin{array}{c}8 \\
23.5 \\
\end{array}$ & $\begin{array}{c}7 \\
22.6 \\
\end{array}$ & $\begin{array}{c}3 \\
15.8 \\
\end{array}$ & $\begin{array}{c}37 \\
22.4 \\
\end{array}$ \\
\hline Critical Thinking & $\begin{array}{c}\mathbf{n} \\
\%\end{array}$ & $\begin{array}{c}3 \\
13.0 \\
\end{array}$ & $\begin{array}{c}6 \\
19.4 \\
\end{array}$ & $\begin{array}{c}8 \\
29.6 \\
\end{array}$ & $\begin{array}{c}6 \\
17.6 \\
\end{array}$ & $\begin{array}{c}7 \\
22.6 \\
\end{array}$ & $\begin{array}{c}6 \\
31.6 \\
\end{array}$ & $\begin{array}{c}36 \\
21.8 \\
\end{array}$ \\
\hline Problem-Solving & $\begin{array}{l}\mathbf{n} \\
\%\end{array}$ & $\begin{array}{c}2 \\
8.7 \\
\end{array}$ & $\begin{array}{c}4 \\
12.9 \\
\end{array}$ & $\begin{array}{c}7 \\
25.9 \\
\end{array}$ & $\begin{array}{c}8 \\
23.5 \\
\end{array}$ & $\begin{array}{c}5 \\
16.1 \\
\end{array}$ & $\begin{array}{c}3 \\
15.8 \\
\end{array}$ & $\begin{array}{c}29 \\
17.6 \\
\end{array}$ \\
\hline Team Building & $\begin{array}{l}\text { n } \\
\%\end{array}$ & $\begin{array}{c}4 \\
17.4 \\
\end{array}$ & $\begin{array}{c}4 \\
12.9 \\
\end{array}$ & $\begin{array}{c}4 \\
14.8 \\
\end{array}$ & $\begin{array}{c}5 \\
14.7 \\
\end{array}$ & $\begin{array}{c}5 \\
16.1 \\
\end{array}$ & $\begin{array}{c}4 \\
21.1 \\
\end{array}$ & $\begin{array}{c}26 \\
15.8 \\
\end{array}$ \\
\hline Presentation & $\begin{array}{l}\mathrm{n} \\
\%\end{array}$ & $\begin{array}{c}6 \\
26.1 \\
\end{array}$ & $\begin{array}{c}4 \\
12.9 \\
\end{array}$ & $\begin{array}{c}2 \\
7.4 \\
\end{array}$ & $\begin{array}{c}1 \\
2.9 \\
\end{array}$ & $\begin{array}{c}1 \\
3.2 \\
\end{array}$ & $\begin{array}{c}1 \\
5.3 \\
\end{array}$ & $\begin{array}{l}15 \\
9.1 \\
\end{array}$ \\
\hline Computer & $\begin{array}{l}\mathbf{n} \\
\%\end{array}$ & $\begin{array}{c}1 \\
4.3 \\
\end{array}$ & $\begin{array}{c}2 \\
6.5 \\
\end{array}$ & $\begin{array}{c}0 \\
0.0 \\
\end{array}$ & $\begin{array}{c}2 \\
5.9 \\
\end{array}$ & $\begin{array}{c}3 \\
9.7 \\
\end{array}$ & $\begin{array}{c}0 \\
0.0 \\
\end{array}$ & $\begin{array}{c}8 \\
4.8 \\
\end{array}$ \\
\hline Interpersonal & $\begin{array}{r}\mathbf{n} \\
\%\end{array}$ & $\begin{array}{c}1 \\
4.3 \\
\end{array}$ & $\begin{array}{c}2 \\
6.5 \\
\end{array}$ & $\begin{array}{c}1 \\
3.7 \\
\end{array}$ & $\begin{array}{c}1 \\
2.9 \\
\end{array}$ & $\begin{array}{c}1 \\
3.2 \\
\end{array}$ & $\begin{array}{c}1 \\
5.3 \\
\end{array}$ & $\begin{array}{c}7 \\
4.2 \\
\end{array}$ \\
\hline Work Independently & \% & $\begin{array}{c}0 \\
0.0 \\
\end{array}$ & $\begin{array}{c}0 \\
0.0 \\
\end{array}$ & $\begin{array}{c}0 \\
0.0\end{array}$ & $\begin{array}{c}2 \\
5.9 \\
\end{array}$ & $\begin{array}{c}1 \\
3.2 \\
\end{array}$ & $\begin{array}{c}1 \\
5.3 \\
\end{array}$ & $\begin{array}{c}4 \\
2.4 \\
\end{array}$ \\
\hline Writing & $\begin{array}{l}\mathbf{n} \\
\%\end{array}$ & $\begin{array}{c}1 \\
4.3 \\
\end{array}$ & $\begin{array}{c}0 \\
0.0 \\
\end{array}$ & $\begin{array}{c}0 \\
0.0 \\
\end{array}$ & $\begin{array}{c}1 \\
2.9 \\
\end{array}$ & $\begin{array}{c}1 \\
3.2 \\
\end{array}$ & $\begin{array}{c}0 \\
0.0 \\
\end{array}$ & $\begin{array}{c}3 \\
1.8 \\
\end{array}$ \\
\hline Totals & $\begin{array}{l}\mathbf{n} \\
\% \\
\end{array}$ & $\begin{array}{c}23 \\
100.0 \\
\end{array}$ & $\begin{array}{c}31 \\
100.0 \\
\end{array}$ & $\begin{array}{c}27 \\
100.0 \\
\end{array}$ & $\begin{array}{c}34 \\
100.0 \\
\end{array}$ & $\begin{array}{c}31 \\
100.0 \\
\end{array}$ & $\begin{array}{c}19 \\
100.0 \\
\end{array}$ & $\begin{array}{c}165 \\
100.0 \\
\end{array}$ \\
\hline
\end{tabular}

Table 6

Rankings Of Skills Deemed To Be Most Improved

\begin{tabular}{|l|c|c|c|c|c|c|c|}
\hline & $\mathbf{1 9 9 5}$ & $\mathbf{1 9 9 6}$ & $\mathbf{1 9 9 7}$ & $\mathbf{1 9 9 8}$ & $\mathbf{1 9 9 9}$ & $\mathbf{2 0 0 0}$ & Overall \\
\hline Quantitative & 2 & 1 & 3 & 1.5 & 1.5 & 3.5 & 1 \\
\hline Critical Thinking & 4 & 2 & 1 & 3 & 1.5 & 1 & 2 \\
\hline Problem-Solving & 5 & 4 & 2 & 1.5 & 3.5 & 3.5 & 3 \\
\hline Team Building & 3 & 4 & 4 & 4 & 3.5 & 2 & 4 \\
\hline Presentation & 1 & 4 & 5 & 8 & 7.5 & 6 & 5 \\
\hline Computer & 7 & 6.5 & 8 & 5.5 & 5 & 8.5 & 6 \\
\hline Interpersonal & 7 & 6.5 & 6 & 8 & 7.5 & 6 & 7 \\
\hline Work Independently & 9 & 8.5 & 8 & 5.5 & 7.5 & 6 & 8 \\
\hline Writing & 7 & 8.5 & 8 & 8 & 7.5 & 8.5 & 9 \\
\hline
\end{tabular}

Note: If two or more skills tie for a ranking, they are all given the average ranking that would have occurred had the scores differed by some small amount. 
With respect to the most improved skill, Quantitative and Critical Thinking clearly occupy the top two positions. The high ranking of Quantitative skills surprised us. Our program is not highly quantitative, and students often complain about the amount of work in statistics and management science. It is very comforting to have had our students rate the improvement of Critical Thinking skills so highly. According to the ratings and rankings, the next two most improved skills were Problem-Solving and Team Building. Presentation skills followed next in fifth place on the list of most improved skills. The final four skills were not often identified as most improved. They are, along with their overall or total percent from Table 5: Computer (4.8\%), Interpersonal (4.2\%), Work Independently (2.4\%), and Writing (1.8\%). Once again, it must be kept in mind that these ratings and rankings were given with respect to the single most improved skill. The final table of this work, Table 12, will present aggregate compilations of first, second, and third mentions of most improved skills, as well as least successfully developed and most important skills.

\section{Ratings Of Skills That Were Least Successfully Developed}

One would expect results of ratings and rankings of the least successfully developed skills to display an inverse relationship with respect to the ratings and rankings of the most improved skills. That is not the case however. For example, consider two respondents who each rated Quantitative as the most improved skill. One of these may have identified Writing as the least successfully developed skill, while the other may have selected Critical Thinking as least successfully developed.

Table 7

Least Successfully Developed Skill

\begin{tabular}{|c|c|c|c|c|c|c|c|c|}
\hline & & 1995 & 1996 & 1997 & 1998 & 1999 & 2000 & Totals \\
\hline Computer & $\begin{array}{l}\mathrm{n} \\
\%\end{array}$ & $\begin{array}{c}9 \\
45.0\end{array}$ & $\begin{array}{c}11 \\
37.9\end{array}$ & $\begin{array}{c}7 \\
31.8\end{array}$ & $\begin{array}{c}5 \\
17.2\end{array}$ & $\begin{array}{c}11 \\
45.8\end{array}$ & $\begin{array}{c}4 \\
23.5\end{array}$ & $\begin{array}{c}47 \\
33.3\end{array}$ \\
\hline Writing & $\begin{array}{r}\mathbf{n} \\
\%\end{array}$ & $\begin{array}{c}3 \\
15.0\end{array}$ & $\begin{array}{c}7 \\
24.1\end{array}$ & $\begin{array}{c}6 \\
27.3 \\
\end{array}$ & $\begin{array}{c}6 \\
20.7\end{array}$ & $\begin{array}{c}5 \\
20.8 \\
\end{array}$ & $\begin{array}{c}2 \\
11.8\end{array}$ & $\begin{array}{c}29 \\
20.6\end{array}$ \\
\hline Interpersonal & n & $\begin{array}{c}0 \\
0.0\end{array}$ & $\begin{array}{c}5 \\
17.2\end{array}$ & $\begin{array}{c}1 \\
4.5\end{array}$ & $\begin{array}{c}6 \\
20.7\end{array}$ & $\begin{array}{c}1 \\
4.2\end{array}$ & $\begin{array}{c}0 \\
0.0\end{array}$ & $\begin{array}{l}13 \\
9.2\end{array}$ \\
\hline Presentation & $\begin{array}{l}\mathrm{n} \\
\%\end{array}$ & $\begin{array}{c}1 \\
5.0\end{array}$ & $\begin{array}{c}2 \\
6.9\end{array}$ & $\begin{array}{c}3 \\
13.6\end{array}$ & $\begin{array}{c}1 \\
3.4\end{array}$ & $\begin{array}{c}3 \\
12.5\end{array}$ & $\begin{array}{c}2 \\
11.8\end{array}$ & $\begin{array}{l}12 \\
8.5\end{array}$ \\
\hline Work Independently & n & $\begin{array}{c}3 \\
15.0\end{array}$ & $\begin{array}{c}0 \\
0.0\end{array}$ & $\begin{array}{c}2 \\
9.1\end{array}$ & $\begin{array}{c}2 \\
6.9 \\
\end{array}$ & $\begin{array}{c}0 \\
0.0\end{array}$ & $\begin{array}{c}5 \\
29.4 \\
\end{array}$ & $\begin{array}{l}12 \\
8.5\end{array}$ \\
\hline Team Building & n & $\begin{array}{c}1 \\
5.0\end{array}$ & $\begin{array}{c}1 \\
3.4\end{array}$ & $\begin{array}{c}2 \\
9.1\end{array}$ & $\begin{array}{c}5 \\
17.2 \\
\end{array}$ & $\begin{array}{c}0 \\
0.0\end{array}$ & $\begin{array}{c}1 \\
5.9\end{array}$ & $\begin{array}{l}10 \\
7.1\end{array}$ \\
\hline Quantitative & $\begin{array}{l}\mathbf{n} \\
\%\end{array}$ & $\begin{array}{c}0 \\
0.0 \\
0\end{array}$ & $\begin{array}{c}1 \\
3.4 \\
\end{array}$ & $\begin{array}{c}1 \\
4.5 \\
\end{array}$ & $\begin{array}{c}1 \\
3.4 \\
\end{array}$ & $\begin{array}{c}3 \\
12.5 \\
\end{array}$ & $\begin{array}{c}3 \\
17.6 \\
\end{array}$ & $\begin{array}{c}9 \\
6.4 \\
\end{array}$ \\
\hline Critical Thinking & $\begin{array}{l}\mathbf{n} \\
\%\end{array}$ & $\begin{array}{c}2 \\
10.0\end{array}$ & $\begin{array}{c}1 \\
3.4\end{array}$ & $\begin{array}{c}0 \\
0.0\end{array}$ & $\begin{array}{c}3 \\
10.3\end{array}$ & $\begin{array}{c}1 \\
4.2\end{array}$ & $\begin{array}{c}0 \\
0.0\end{array}$ & $\begin{array}{c}7 \\
5.0\end{array}$ \\
\hline Problem-Solving & $\begin{array}{l}\mathrm{n} \\
\%\end{array}$ & $\begin{array}{c}1 \\
5.0\end{array}$ & $\begin{array}{c}1 \\
3.4\end{array}$ & $\begin{array}{c}0 \\
0.0\end{array}$ & $\begin{array}{c}0 \\
0.0\end{array}$ & $\begin{array}{c}0 \\
0.0\end{array}$ & $\begin{array}{c}0 \\
0.0\end{array}$ & $\begin{array}{c}2 \\
1.4\end{array}$ \\
\hline Totals & $\begin{array}{l}\text { n } \\
\%\end{array}$ & $\begin{array}{c}20 \\
100.0 \\
\end{array}$ & $\begin{array}{c}29 \\
100.0 \\
\end{array}$ & $\begin{array}{c}22 \\
100.0 \\
\end{array}$ & $\begin{array}{c}29 \\
100.0 \\
\end{array}$ & $\begin{array}{c}24 \\
100.0 \\
\end{array}$ & $\begin{array}{c}17 \\
100.0 \\
\end{array}$ & $\begin{array}{c}141 \\
100.0 \\
\end{array}$ \\
\hline
\end{tabular}


Table 8

Rankings Of Skills Deemed To Be Least Successfully Developed

\begin{tabular}{|l|c|c|c|c|c|c|c|}
\hline & $\mathbf{1 9 9 5}$ & $\mathbf{1 9 9 6}$ & $\mathbf{1 9 9 7}$ & $\mathbf{1 9 9 8}$ & $\mathbf{1 9 9 9}$ & $\mathbf{2 0 0 0}$ & Overall \\
\hline Computer & 1 & 1 & 1 & 3.5 & 1 & 2 & 1 \\
\hline Writing & 2.5 & 2 & 2 & 1.5 & 2 & 4.5 & 2 \\
\hline Interpersonal & 8.5 & 3 & 6.5 & 1.5 & 5.5 & 8 & 3 \\
\hline Presentation & 6 & 4 & 3 & 7.5 & 3.5 & 4.5 & 4.5 \\
\hline Work Independently & 2.5 & 9 & 4.5 & 6 & 8 & 1 & 4.5 \\
\hline Team Building & 6 & 6.5 & 4.5 & 3.5 & 8 & 6 & 6 \\
\hline Quantitative & 8.5 & 6.5 & 6.5 & 7.5 & 3.5 & 3 & 7 \\
\hline Critical Thinking & 4 & 6.5 & 8.5 & 5 & 5.5 & 8 & 8 \\
\hline Problem-Solving & 6 & 6.5 & 8.5 & 9 & 8 & 8 & 9 \\
\hline
\end{tabular}

Nonetheless, the results of Tables 7 and 8 support the conclusions derived from Tables 5 and 6 . Computer and Writing skills were clearly identified as the least successfully developed (they also received little support for most improved in Tables 5 and 6). Working down the list of least successfully developed skills we find Interpersonal, Presentation, Work Independently, and Team Building. The skills receiving the lowest ratings on least successfully developed were Quantitative, Critical Thinking, and Problem-Solving, and these are the skills that were most highly rated as most improved.

\section{Ratings Of Skills That Were Most Important To Professional Goals And Development}

The final survey item concerned with the nine skills directed respondents to identify the skills that were most important to their professional goals and development. This is extremely important information for any student group, but of even more paramount importance since the respondents are MBA alumni actively employed and engaged in career development and advancement. Basically, Tables 5 through 8 depict results that provide information concerning:

1. how effective our curriculum content has been in providing coverage of these skills, and/or

2. how effective the delivery system (classroom experiences, on-line coursework, assignments, etc.) has been in providing exposure to and development of these skills.

Table 9 shows clearly that in the opinions of our MBA alumni, the most important skills are Critical Thinking and Problem-Solving. Over the years of $1997-2000$, these two skills were consistently ranked as first or second most important. Interestingly, Presentation skills were ranked as first most important in 1995 and 1996, and then fell off a bit in the succeeding four years. The data beg a variety of questions such as:

1. Why did the respondents rate Writing skills so low? We are always hearing from the business community that written and oral communication skills are highly valued.

2. How do the respondents define Problem-Solving? This term encompasses a variety of skills, and some students may be incorrectly equating Problem-Solving and Quantitative skills.

3. How should the administration and faculty utilize these data to improve the curriculum and its delivery system? 
Table 9

Skill Most Important To Professional Goals And Development

\begin{tabular}{|c|c|c|c|c|c|c|c|c|}
\hline & & 1995 & 1996 & 1997 & 1998 & 1999 & 2000 & Totals \\
\hline Critical Thinking & n & $\begin{array}{c}3 \\
13.6\end{array}$ & $\begin{array}{c}6 \\
19.4\end{array}$ & $\begin{array}{c}11 \\
40.7\end{array}$ & $\begin{array}{c}12 \\
34.3\end{array}$ & $\begin{array}{c}9 \\
29.0\end{array}$ & $\begin{array}{c}3 \\
15.8\end{array}$ & $\begin{array}{c}44 \\
26.7\end{array}$ \\
\hline Problem-Solving & n & $\begin{array}{c}1 \\
4.5\end{array}$ & $\begin{array}{c}5 \\
16.1 \\
\end{array}$ & $\begin{array}{c}8 \\
29.6\end{array}$ & $\begin{array}{c}9 \\
25.7\end{array}$ & $\begin{array}{c}9 \\
29.0\end{array}$ & $\begin{array}{c}6 \\
31.6 \\
\end{array}$ & $\begin{array}{c}38 \\
23.0\end{array}$ \\
\hline Presentation & \% & $\begin{array}{c}9 \\
40.9\end{array}$ & $\begin{array}{c}7 \\
22.6 \\
\end{array}$ & $\begin{array}{c}1 \\
3.7\end{array}$ & $\begin{array}{c}4 \\
11.4\end{array}$ & $\begin{array}{c}0 \\
0.0\end{array}$ & $\begin{array}{c}2 \\
10.5\end{array}$ & $\begin{array}{c}23 \\
13.9\end{array}$ \\
\hline Team Building & n & $\begin{array}{c}4 \\
18.2 \\
\end{array}$ & $\begin{array}{c}3 \\
9.7 \\
\end{array}$ & $\begin{array}{c}3 \\
11.1 \\
\end{array}$ & $\begin{array}{c}4 \\
11.4 \\
\end{array}$ & $\begin{array}{c}1 \\
3.2 \\
\end{array}$ & $\begin{array}{c}1 \\
5.3\end{array}$ & $\begin{array}{l}16 \\
9.7 \\
\end{array}$ \\
\hline Interpersonal & n & $\begin{array}{c}1 \\
4.5 \\
\end{array}$ & $\begin{array}{c}4 \\
12.9 \\
\end{array}$ & $\begin{array}{c}1 \\
3.7\end{array}$ & $\begin{array}{c}3 \\
8.6 \\
\end{array}$ & $\begin{array}{c}5 \\
16.1 \\
\end{array}$ & $\begin{array}{c}2 \\
10.5\end{array}$ & $\begin{array}{l}16 \\
9.7\end{array}$ \\
\hline Quantitative & $\begin{array}{l}\mathbf{n} \\
\%\end{array}$ & $\begin{array}{c}2 \\
9.1 \\
\end{array}$ & $\begin{array}{c}2 \\
6.5\end{array}$ & $\begin{array}{c}2 \\
7.4\end{array}$ & $\begin{array}{c}1 \\
2.9\end{array}$ & $\begin{array}{c}2 \\
6.5\end{array}$ & $\begin{array}{c}2 \\
10.5\end{array}$ & $\begin{array}{l}11 \\
6.7 \\
\end{array}$ \\
\hline Computer & $\begin{array}{l}\mathbf{n} \\
\%\end{array}$ & $\begin{array}{c}0 \\
0.0\end{array}$ & $\begin{array}{c}2 \\
6.5\end{array}$ & $\begin{array}{c}0 \\
0.0\end{array}$ & $\begin{array}{c}1 \\
2.9\end{array}$ & $\begin{array}{c}4 \\
12.9\end{array}$ & $\begin{array}{c}1 \\
5.3\end{array}$ & $\begin{array}{c}8 \\
4.8 \\
\end{array}$ \\
\hline Work Independently & n & $\begin{array}{c}1 \\
4.5 \\
\end{array}$ & $\begin{array}{c}1 \\
3.2 \\
\end{array}$ & $\begin{array}{c}1 \\
3.7 \\
\end{array}$ & $\begin{array}{c}0 \\
0.0\end{array}$ & $\begin{array}{c}1 \\
3.2 \\
\end{array}$ & $\begin{array}{c}2 \\
10.5 \\
\end{array}$ & $\begin{array}{c}6 \\
3.6 \\
\end{array}$ \\
\hline Writing & $\begin{array}{r}\mathrm{n} \\
\%\end{array}$ & $\begin{array}{c}1 \\
4.5 \\
\end{array}$ & $\begin{array}{c}1 \\
3.2 \\
\end{array}$ & $\begin{array}{c}0 \\
0.0 \\
\end{array}$ & $\begin{array}{c}1 \\
2.9 \\
\end{array}$ & $\begin{array}{c}0 \\
0.0 \\
\end{array}$ & $\begin{array}{c}0 \\
0.0 \\
\end{array}$ & $\begin{array}{c}3 \\
1.8 \\
\end{array}$ \\
\hline Totals & $\begin{array}{l}\mathrm{n} \\
\%\end{array}$ & $\begin{array}{c}22 \\
100.0 \\
\end{array}$ & $\begin{array}{c}31 \\
100.0 \\
\end{array}$ & $\begin{array}{c}27 \\
100.0 \\
\end{array}$ & $\begin{array}{c}35 \\
100.0 \\
\end{array}$ & $\begin{array}{c}31 \\
100.0 \\
\end{array}$ & $\begin{array}{c}19 \\
100.0 \\
\end{array}$ & $\begin{array}{c}165 \\
100.0 \\
\end{array}$ \\
\hline
\end{tabular}

Table 10

Rankings Of Skills Deemed To Be Most Important to Professional Goals And Development

\begin{tabular}{|l|c|c|c|c|c|c|c|}
\hline & $\mathbf{1 9 9 5}$ & $\mathbf{1 9 9 6}$ & $\mathbf{1 9 9 7}$ & $\mathbf{1 9 9 8}$ & $\mathbf{1 9 9 9}$ & $\mathbf{2 0 0 0}$ & Overall \\
\hline Critical Thinking & 3 & 2 & 1 & 1 & 1.5 & 2 & 1 \\
\hline Problem-Solving & 6.5 & 3 & 2 & 2 & 1.5 & 1 & 2 \\
\hline Presentation & 1 & 1 & 6 & 3.5 & 8.5 & 4.5 & 3 \\
\hline Team Building & 2 & 5 & 3 & 3.5 & 6.5 & 7.7 & 4.5 \\
\hline Interpersonal & 6.5 & 4 & 6 & 5 & 3 & 4.5 & 4.5 \\
\hline Quantitative & 4 & 6.5 & 4 & 7 & 5 & 4.5 & 6 \\
\hline Computer & 9 & 6.5 & 8.5 & 7 & 4 & 7.5 & 7 \\
\hline Work Independently & 6.5 & 8.5 & 6 & 9 & 6.5 & 4.5 & 8 \\
\hline Writing & 6.5 & 8.5 & 8.5 & 7 & 8.5 & 9 & 9 \\
\hline
\end{tabular}

\section{Comparisons Between Ratings of Most Important and Most Improved Skills}

Table 11 presents an interesting view of the data concerning these nine critical skills. Its goal is to depict comparisons between ratings of the most important skills and the most improved skills. For each skill, the overall percents (compiled over the years 1995 - 2000) are shown for respondents who rated that skill as most important and for those who rated it as most improved. Then, a difference score is computed for each skill as:

Percent who rated the skill as most important - percent who rated the skill as most improved.

Thus, the computation for critical thinking is $26.7 \%-21.8 \%=+4.9 \%$. Basically, positive differences occur when there were more respondents who rated the skill as most important than there were respondents who rated the skill as most improved. In like manner, negative differences mean that a larger percent of respondents rated the skill as most improved. Only positive differences would appear to be potentially problematic. An interpretation of a positive difference is that the respondents showed more enthusiasm concerning the skill's importance than they showed for its improvement. Note that Critical Thinking and Problem-Solving have difference 
scores of $+4.9 \%$ and $+5.4 \%$ respectively. There really does not appear to be a problem with these skills if one also looks at the rankings. These skills were ranked first and second on the most important scale, and ranked second and third on the most improved scale. However, Interpersonal skills, with a difference score of $+5.5 \%$ may deserve some attention. Interpersonal skills attained a ranking of 4.5 on the most important scale, and a ranking of only 7 on the most improved scale. Brainstorming at the departmental and at the business school levels may divulge methods to enhance the development of interpersonal skills.

Table 11

Difference Scores Between The Most Important Percent And The Most Improved Percent

\begin{tabular}{|c|c|c|c|c|c|}
\hline \multirow[t]{2}{*}{ Skill } & \multicolumn{2}{|c|}{$\begin{array}{c}\text { Most Important } \\
\text { Skill }\end{array}$} & \multicolumn{2}{|c|}{$\begin{array}{c}\text { Most Improved } \\
\text { Skill }\end{array}$} & \multirow{2}{*}{$\begin{array}{c}\text { DIFFERENCES } \\
\text { Most Important \% } \\
\text { - Most Improved \% } \\
\text { Percents }\end{array}$} \\
\hline & Rank & Percent & Rank & Percent & \\
\hline Critical Thinking & 1 & 26.7 & 2 & 21.8 & +4.9 \\
\hline Problem-Solving & 2 & 23.0 & 3 & 17.6 & +5.4 \\
\hline Presentation & 3 & 13.9 & 5 & 9.1 & +4.8 \\
\hline Team Building & 4.5 & 9.7 & 4 & 15.8 & -6.1 \\
\hline Interpersonal & 4.5 & 9.7 & 7 & 4.2 & +5.5 \\
\hline Quantitative & 6 & 6.7 & 1 & 22.4 & -15.7 \\
\hline Computer & 7 & 4.8 & 6 & 4.8 & 0 \\
\hline Work Independently. & 8 & 3.6 & 8 & 2.4 & +1.2 \\
\hline Writing & 9 & 1.8 & 9 & 1.8 & 0 \\
\hline
\end{tabular}

\section{Comparisons Among Aggregate Ratings of Most Improved, Most Important, and Least Successfully Developed Skills}

In Table 12, the data have been aggregated over the first, second, and third choice responses to the three items concerned with the critical skills. The big difference between data in Tables $5-11$ versus data in Table 12 is that the former display results of first choice responses only, while Table 12 compiles first, second, and third mentions and presents a total number of mentions of each skill. Using Most Important Skill as an example, we see that 166 respondents (of the total 167 respondents) listed at least one skill as being most important. Of those 166 respondents, 66.3 percent (110 respondents) identified Problem-Solving as being either the first, second, or third most important skill. As another example, of the 141 respondents who listed at least one skill as being Least Successfully Developed, 31.2 percent named Interpersonal Skills as either their first, second, or third choice.

Table 12

Aggregate Mentions (as $1^{\text {st }}, 2^{\text {nd }}$, or $3^{\text {rd }}$ choice) Of Skill Assessments

\begin{tabular}{|c|c|c|c|c|c|c|}
\hline \multirow[t]{2}{*}{ Skill } & \multicolumn{2}{|c|}{$\begin{array}{c}\text { Most Important } \\
\text { Skill } \\
\mathrm{n}=166\end{array}$} & \multicolumn{2}{|c|}{$\begin{array}{c}\text { Most Improved } \\
\text { Skill } \\
n=165\end{array}$} & \multicolumn{2}{|c|}{$\begin{array}{c}\text { Least Successfully } \\
\text { Developed Skill } \\
\mathbf{n}=\mathbf{1 4 1}\end{array}$} \\
\hline & Rank & *Percent & Rank & Percent & Rank & Percent \\
\hline Problem-Solving & 1 & 66.3 & 1 & 53.3 & 9 & 9.2 \\
\hline Critical Thinking & 2 & 59.6 & 2 & 52.1 & 8 & 17.7 \\
\hline Team Building & 3 & 41.0 & 5 & 39.4 & 6 & 22.7 \\
\hline Interpersonal & 4 & 40.4 & 8 & 14.5 & 3 & 31.2 \\
\hline Presentation & 5 & 34.3 & 3.5 & 45.5 & 5 & 26.2 \\
\hline Quantitative & 6 & 19.9 & 3.5 & 45.5 & 7 & 22.0 \\
\hline Computer & 7 & 13.3 & 6 & 16.4 & 1 & 57.4 \\
\hline Writing & 8 & 11.4 & 7 & 15.2 & 2 & 47.5 \\
\hline Work Independently. & 9 & 6.6 & 9 & 9.1 & 4 & 29.1 \\
\hline
\end{tabular}

*Percent refers to the percent of respondents who named the skill as one of three possible responses, i.e., Most Important, $2^{\text {nd }}$ Most Important, or $3^{\text {rd }}$ Most Important. 
It is comforting to note that the two most important skills - Problem-Solving and Critical Thinking - are also the two most improved skills to our MBA alumni. Attention should be directed towards skills that were rated higher on the importance scale that they were on the improved scale. Once again, Interpersonal Skills is problematic. 40.4 percent of the respondents listed it as one of three choices on the importance scale, and only 14.5 percent identified Interpersonal Skills on the most improved scale. No other skill raises a red flag. Note that Quantitative Skills display a big difference between mentions as most important (19.9\%) and most improved (45.5\%). Such differences occurring as a result of the improved rating being stronger than the importance rating are not at all problematic.

\section{Importance Of Critical Skills}

Tables 9 and 10 reveal that there were three tiers evident in the data, with tier 1 representing the highest ratings of importance to our MBA alumni.

Tier 1 - Critical Thinking and Problem-Solving Skills

Tier 2 - Presentation, Team Building, Interpersonal, and Quantitative Skills

Tier 3 - Computer Skills, Work Independently, and Writing

\section{CONCLUSIONS}

These results support findings represented in Table 4, which summarized the reasons that our MBA alumni told us that they would recommend our program. Recall that three of the top four reasons were Faculty Competence, Quality of Program, and Program Reputation. The "quality" dimensions of our MBA program were the most salient attributes that caused our alumni to recommend our program. The MBA alumni expressed support for the development of skills requisite for upper management. They seem to be most concerned with the "big picture" as they appear to be eager to gain tools that will help them solve real world problems and enhance their ability to think. The three tiers of skills in Tables 9 and 10 also comport extremely well with findings in earlier studies of newly matriculating MBAs (Glynn, 2004) wherein the new MBA students identified the same three tiers of skills when asked to rate the importance of these same nine critical skills.

Three of the skills represented on tier 2 are Presentation, Team Building, and Interpersonal Skills. These are related to interactions with co-workers in the workplace. Most of our MBA alumni are professionally employed and know the value and importance of working well with others, getting along, being a team player, and being able to communicate and present ideas. Still, they rate these skill as secondary to the more rigorous critical thinking and problem-solving skills of tier 1.

\section{Implications For Curriculum Development}

The knowledge that our MBA alumni expect and want the skills discussed above to be emphasized is very useful to us in curriculum design and individual course development. The quality dimensions of our program are most important to our MBA alumni, and also to our current MBA students (Glynn, 2004, 2005). We should be very cognizant of the importance of maintenance of standards, and thus the preservation of the quality of our program and its reputation.

Other sections of our survey (Tables 3 and 4 as well as other survey results not herein reported) have divulged that MBA alumni value real world business experience of our faculty and real world classroom exercises. The MBA curriculum should be emphasizing group problem-solving activities, student classroom presentations, perhaps case studies and/or business simulation games, integration of material both within and across courses, and real world problems. Faculty classroom presentations should incorporate guest speakers/lecturers. These may be local business leaders, perhaps some MBA alumni who can relate real world business successes to their MBA program experiences. 


\section{Caveats}

Deductions concerning critical skills that were identified by respondents as most improved must be carefully made, and even then, evaluated in light of the following caveat. A review of Table 5 (or the Most Improved Skill portion of Table 12) shows that Quantitative and Critical Thinking skills were clearly identified as most improved, and Computer, Interpersonal, Work Independently, and Writing skills received very little support as most improved. There are many scenarios that could result in a skill not being identified as significantly improved.

The reader should consider the following reasons that a skill might be or not be listed as one of three most improved skills:

1. The rankings of most improved may "naturally" mirror the rankings of most important skills. That is, if MBA alumni are generally satisfied with and supportive of their MBA program, and ours are, there might be a natural tendency to rate the skills that are most important highly on a most improved scale.

2. Prior to matriculation in our MBA program, the skill may already have been strong or well developed. For example, many of our MBA students come to the program with superior computer skills. When given the opportunity to identify at most three skills that are most improved, it is unlikely that computer skills would be listed.

\section{REFERENCES}

1. AACSB Task Force on Outcome Measurement. (June, 1989). Report of the AACSB Task Force on Outcome Measurement.

2. AACSB International - The Association to Advance Collegiate Schools of Business International. (April, 2003, Revised January, 2004). Eligibility Procedures and Standards for Business Accreditation.

3. Hanna Ashar, Maureen Lane. Focus Groups Help to Focus Marketing Strategy. Journal of Marketing for Higher Education: Volume 7, Number 2, 1996.

4. Beverly A. Browne, Dennis O Kaldenberg, William G. Browne, Daniel J. Brown. Student as Customer: Factors Affecting Satisfaction and Assessments of Institutional Quality Journal of Marketing for Higher Education: Volume 8, Number 3, 1998.

5. Frank J. Franzak, Deborah L. Cowles. Viewing the Curriculum as a Product: Implications from a Marketing Research Study. Journal of Marketing for Higher Education: Volume 4, Number 1-2, 1993

6. Joseph G. Glynn. Expectations of Incoming MBA Students: Implications for Curriculum Development and Program Promotion. Journal of Business \& Economics Research: Volume 2, Number 2, February, 2004.

7. Joseph G. Glynn. MBA Student Pre-Program and Post-Program Assessment of Critical Skills: Implications for Outcomes Assessment and Curriculum Design. Journal of College Teaching \& Learning: Volume 2, Number 2, February, 2005.

8. Mathew Joseph, Beatrice Joseph. Employer Perceptions of Service Quality in Higher Education. Journal of Marketing for Higher Education: Volume 8, Number 2, 1997.

9. Eric Panitz. Part-time MBA Students Expectations of their MBA Experience. Journal of Marketing for Higher Education: Volume 6, Number 1, 1995. 
NOTES 